\title{
Short Communication: \\ Characterization of Rhizoctonia-like mycorrhizae associated with five Dendrobium species in Java, Indonesia
}

\author{
R. SOELISTIJONO ${ }^{1, \boldsymbol{v}}$, D.S. UTAMI ${ }^{1}$, DARYANTI ${ }^{1}$, M. FAIZIN ${ }^{2}$, R. DIAN ${ }^{3}$ \\ ${ }^{1}$ Faculty of Agriculture, Universitas Tunas Pembangunan. Jl. Balekambang No. 1, Manahan, Surakarta 57139, Central Java, Indonesia. \\ Tel.: +62-271-710644, `email: sulistyo.utp@gmail.com \\ ${ }^{2}$ School Graduates, Faculty of Agriculture, Universitas Tunas Pembangunan. J1. Balekambang No. 1, Manahan, Surakarta 57139, Central Java, Indonesia \\ ${ }^{3}$ Magelang District's Agriculture and Food Service. Jl. Letnan Tukiyat, Mungkid, Magelang 56511, Central Java, Indonesia
}

Manuscript received: 30 September 2019. Revision accepted: 11 February 2020.

\begin{abstract}
Soelistijono R, Utami DS, Daryanti, Faizin M, Dian R. 2020. Plankton biodiversity in various typologies of inundation in Paminggir swamp, South Kalimantan, Indonesia on dry season. Biodiversitas 21: 1007-1011. This study aims to determine the morphological and anatomical characteristics of Rhizoctonia-like mycorrhizae associated with the roots of five Dendrobium species; to determine the association between Rhizoctonia-like mycorrhizae with the root of five Dendrobium sp.; to obtain difference between Rhizoctonia-like mycorrhizae with the other in adjacent location Mycorrhizal observations of Rhizoctonia-like mycorrhizae in this study were carried out macroscopically (morphologically) and microscopically (anatomically). The macroscopic observation was performed by observing directly the development of fungal colonies on culture media. Microscopic observations were performed to determine the shape of the hyphal of fungi and the number of nuclei. The results showed that the Rhizoctonia-like mycorrhizae associated with the root of five species of Dendrobium sp. in Java were the binucleate Rhizoctonia groups (BNR). The binucleate Rhizoctonia has white colonies, right-angle branching hyphae, two nuclei, and brown hyphae. The association of the root of five species of Dendrobium sp.with Rhizoctonia-like mycorrhizae fungi was indicated by the existence of a peloton structure in cortical root tissue.
\end{abstract}

Keyword: Dendrobium species, Rhizoctonia-like mycorrhizae, peloton, Java

\section{INTRODUCTION}

Orchid is one type of ornamental plant that has an attractive flower shape and color, is durable, and has a high selling value so that it is widely liked by the wider community (Widiastuti 2010). Apart from being an ornamental plant, some orchids have potential as medicinal plants, for example, Spathoglottis plicata as an ear medicine (Sadili 2011). Orchid belongs to the Orchidaceae family which consists of 800 genera and approximately 25,000 species. Based on the place of life, orchids are divided into 4 groups, namely epiphytes (which grow attached to trees), saprophytes (living in trash/humus), lithophytes (living in rocks), and terrestrial (which grows on the ground).

One of the most common epiphytic orchids is the genus Dendrobium. The Dendrobium genus is one of the largest orchid genus, which is ranked second after the genus Bulbophyllum. This genus has 600 species that spread of Dendrobium species (sp.) is very extensive and can be found from East Asia to the Pacific islands and the Himalayas through Myanmar to spread the Malay Peninsula, Australia, New Zealand, Papua New Guinea, China, Japan, Philippines, and Fiji (Northen 1986).

In nature, orchids need mycorrhizae to be able to grow, including Dendrobium sp. Because like the other orchids, Dendrobium sp. does not have food reserves (endosperm) for its development and growth. Withner (1959) mentioned that orchid seeds have a very small form and do not have endosperm, so natural germination cannot occur. The absence of endosperm (food reserves) in orchid seeds is due to the absence of fusion between the sperm nucleus with the polar nucleus, or because degeneration always occurs after the union of a second sperm nucleus with two polar nuclei that produce a triploid nucleus. In some plants, before degeneration, the triploid nucleus still carries out several cleavages even though no perfect endosperm will be formed (Lenz and Wimber 1959).

In nature, Dendrobium seeds require mycorrhizae in supplying nutrients from the environment for germination (Smith and Read 2008). Through symbiotic relationships with plants, mycorrhizae play an important role in plant growth, disease protection, and overall soil quality improvement. Thus mycorrhizae play an important role in plant productivity (Siddiqui and Pithtel 2008). One of mycorrhizal fungi that is able to associate with the orchids is Rhizoctonia mycorrhizae (Athipunyakom and Manoch 2008). In addition to Rhizoctonia mycorrhizae, other fungi that can be symbiotic with the orchids are the genus Epulorrhiza, Moniliopsis, and Ceratorhiza (Smith and Read 2008). Rhizoctonia mycorrhizae are one of the Rhizoctonia species which has the ability to associate with orchid plants (Hayakawa et al. 1999). Rhizoctonia species consist of 3 groups depending on the number of nuclei. The first group is Rhizoctonia species, which has only 1 nucleus, this group is non-pathogenic. The second group of Rhizoctonia 
species has 2 nuclei, are mycorrhizal in orchids, and the third group has many nuclei, are pathogenic like Rhizoctonia solani (Sneh et al. 1991).

Rhizoctonia mycorrhizae are capable of symbiosis with orchid root tissue and form hyphae twists that attach to the root cortex tissue in orchids. The association of Rhizoctonia mycorrhizae and orchid plants occurs at the stage of embryonic development, then the formation of shoots and roots is known as the stages of protocorm formation. Hyphae from Rhizoctonia mycorrhizae will penetrate orchid seed cell walls and then spread throughout other cell tissues. After the protocorm develops into a perfect plant (plantlet) then Rhizoctonia mycorrhizae hyphae tissue will be in the cortex of the orchid root and form a peloton structure (Senthilkumar et al. 2001).

Peloton is intracellular hyphae which in the cortical root tissue and usually only exist in a certain period before then undergoing lysis. Peloton is an accumulation of organic materials including protein, glycogen, and fat, which is the result of absorption of nutrients from the soil. When it is needed, the orchid embryo will absorb these organic materials for growth so that the peloton will undergoing lysis (George 2008). Peloton is formed from binucleate Rhizoctonia (BNR) hyphae which penetrate and then infect the epidermal cells, then form a solid coil in the root (Brundrett 2004). Infection and peloton lysis occur repeatedly in cells. In orchid tissue culture, peloton will never form in seedling, because there is no association between Rhizoctonia mycorrhizae with orchid seeds. Because orchid seeds grow in the bottle (in vitro), it gets the supply of nutrients directly from growth media such as Murashige and Skoog or Vaccine and Went media.

There are several mycorrhizal fungi associated with Dendrobium sp. such as Mucor and Rhizoctonia (Mufidah et al. 2017.), however, there is no research on comparisons between Rhizoctonia-like mycorrhizae associated with Dendrobium the others in Central Java, Special Region of Yogyakarta, and East Java. Therefore, this study is expected to obtain comparative data on various types of Rhizoctonia-like mycorrhizae that are located close to each other.

\section{MATERIALS AND METHODS}

\section{Study area}

The research was carried out from March 2018 to April 2019 in the Microbiology Laboratory of the Faculty of Agriculture, Tunas Pembangunan University, Surakarta, Indonesia. Several samples of Dendrobium sp. were collected from Java Island, Indonesia, i.e. Dendrobium lasianthera from Kaliurang, Yogyakarta (800 m above sea level/m. asl), Dendrobium lineale blue from Sleman, Yogyakarta (300 m. asl), Dendrobium aphyllum from Surakarta, Central Java (100 m. asl), Dendrobium fimbriatum from Batu, East Java (1000 m. asl), and Dendrobium phalaenopsis from Malang, East Java (500 m. asl). All of the collected Dendrobiums are epiphytes on trees.

\section{Isolation and identification of Rhizoctonia-like mycorrhizae}

Isolation of Rhizoctonia-like mycorrhizae was carried out by cutting the tip of the roots of healthy Dendrobium sp. with a thickness of $3 \mathrm{~mm}$ in the transverse section. Root segments were placed on potato dextrose agar (PDA) in the Petri dish. Sample sterilization was not carried out on Rhizoctonia-like mycorrhizae isolation because it can kill mycorrhizal fungi. So that more than one fungi or bacteria colonies in medium. From several fungi or bacteria colonies obtain isolation was carried out fungi colonies suspected Rhizoctonia-like mycorrhizae. The growing fungi on PDA were purified to obtain pure isolate of Rhizoctonia-like mycorrhizae with the criteria of white colony fungi (Soelistijono 2011).

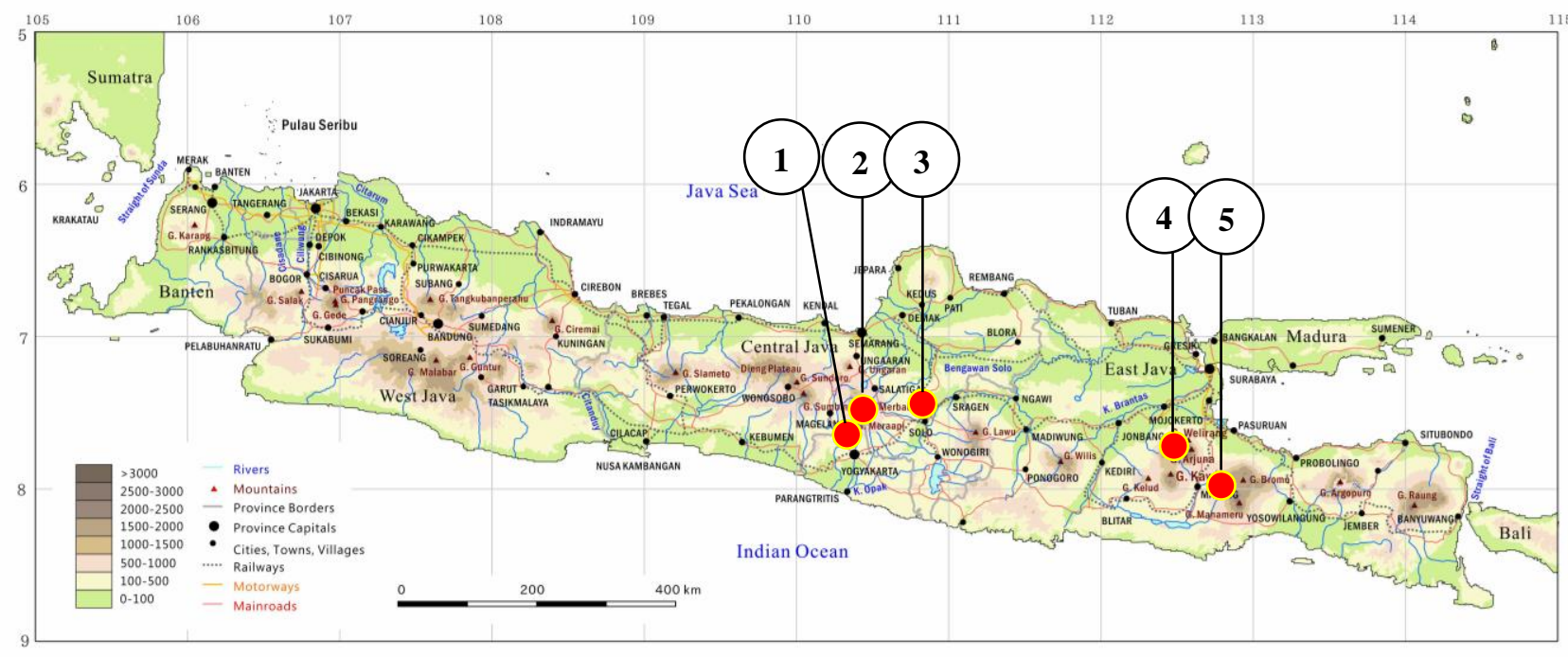

Figure 1. Sampling locations of Dendrobium sp. In Java, Indonesia. 1. Sleman, 2. Kaliurang, 3. Surakarta, 4. Batu, 5. Malang 
Identification of Rhizoctonia-like mycorrhizae was carried out according to Barnett and Hunter (1972). Morphological characteristics were observed, i.e. colony color, branching shape, and the number of nuclei in the cell; while microscopic observation (anatomical) of hyphae structure (peloton) was done under XSZ 107 binocular microscope BN/Oregon/Yazumi at 400 times magnification. Observation of peloton structure was carried out microscopically by observing the presence of hyphal coil in the root tissue based on the method of Senthilkumar et al. (2001) which has been modified for safranin staining. Preparations were made by making cross-sectioned roots of the five species of Dendrobium sp. as thin as possible. Root pieces are placed on the glass object and then put on the glazed object with drops of safranin paint and also $90 \%$ alcohol.

\section{RESULTS AND DISCUSSION}

\section{Diversity of Rhizoctonia-like mycorrhizae associated with Dendrobium sp.}

A total of 17 Rhizoctonia-like mycorrhizae were isolated from Dendrobium sp. Observations of fungal colonies on PDA showed that fungi have a white color. According to Athipunyakom and Manoch (2008), The colony of Rhizoctonia mycorrhizae in orchids are generally white. Macroscopic observations showed that fungal colonies growing on PDA was almost cover the surface of the Petri dish. The observations on the 17 Rhizoctonia-like mycorrhizae from Dendrobium showed that mycorrhizae from D. lasianthera have white (isolates number 1 and 2) and light brown colonies (isolates number 3). Mycorrhizal fungi from $\mathrm{D}$. lineale has a light brown (isolate number 4) and white (isolate number 5, 6, and 7) colony, isolates from D. aphyllum has white colony (isolates number 8,9 , and 10), those from D. fimbriatum have white (isolate number 11, 13 and 14), and light brown colony (isolate number 12), while isolates from D. phalaenopsis have white colony (isolates number 15, 15, and 17). Almost all isolates were 2 nucleated (binucleate). Color differences in the same isolate can occur due to differences in the sporangium maturity. Sporangium maturity affects the color of sporangium from white, brown, and dark. The dark color indicates mature sporangium and is ready to spore out before finally forming sclerotium. Therefore, differences in colony's color can not be used as the main factor to differentiate mycorrhizae isolated from various species of Dendrobium. The identification should be based on the mycelium structure. The mycelium identification was carried out based on Barnett and Hunter (1972) i.e.: (i) colony color, (ii) number of nuclei, and (iii) shape.

\section{Identification of Rhizoctonia-like mycorrhizae}

Figure 2 shows that each isolate has white hyphae and the branching occurs at right angles. Observation shows that the main hyphae are longer and larger in diameter. Small hyphae are branched hyphae from the main hyphae. This is in agreement with Agrios (2005) and Sneh et al. (1991), that hyphae branches on Rhizoctonia mycorrhizae form angular angles and have brown pigment. The study of
Athipunyakom and Manoch (2008), showed that 7 isolates of Rhizoctonia mycorrhizae from Spathoglottis plicata from various places in Thailand had white, brownish-white or light brown colonies. The study of Soelistijono et al., (2011) also showed that 4 isolates of Rhizoctonia mycorrhizae from Spathoglottis plicata from various places in Java had white colonies. The study by Agustini et al., (2009) in the Jayapura Cycloops botanical garden showed that 10 isolates of mycorrhizae from orchid have different and various colors from white to black. Therefore, the color of the colonies of Rhizoctonia-like mycorrhiza is not always white. This is in agreement with Soelistijono (2011) that the colonies of Rhizoctonia-like mycorrhizae differ depending on their groups (isolates grouping).

Sneh et al., (1991) revealed that Rhizoctonia mycorrhizal isolates were included in the binucleate group. Rhizoctonia-like mycorrhizae collected in this study showed that their hyphae cells have two nuclei in each septum, therefore, these isolates can be classified as Binucleate Rhizoctonia-like mycorrhizae (BNR) which have two nuclei. Based on morphological and anatomical characteristics it can be concluded that all of the isolated fungi were Rhizoctonia-like mycorrhizae.

\section{Peloton structure}

Roots of Dendrobium sp. showed the hyphal coil structure in the root cortex as a result of Rhizoctonia-like mycorrhizae association with the root cortex. The study by Zumri et al., (2016) showed the formation of a peloton structure that occurred in the root cortex of Vanda tricolor seedling as a result of the association with Rhizoctonia mycorrhizae as a coil in the space between cells. Crosssection of the orchid root showed that peloton only presence in the cortical tissue, but not found in the other root tissues such as an epidermal or central cylinder. Orchid roots do not have cambium so the nutrient transport is spread outside. The presence of peloton in the root cortex tissue as the food reserves so that nutrients in the peloton can be absorbed and circulated followed by the lysis of peloton.

Smith and Read (2008) stated that Rhizoctonia mycorrhizae are capable of symbiosis with orchid root tissue and form hyphal coils that clump in the cortical root tissue. The nutrient absorption mechanism in the form of peloton structure shows that mycelium of Rhizoctonia mycorrhizae can penetrate the epidermal tissue and root cortex. In the cortex, mycelium enters the intercellular space and form a peloton. Inside the peloton, there is the accumulation of organic materials includes proteins, glycogen and fat and nutrients produced by absorption from the soil. Orchid embryos absorb these organic materials for their growth after that the peloton undergoing lysis (Soelistijono 2015).

Orchids have various heterotrophic levels. Low heterotrophic orchids require the presence of mycorrhizae in obtaining carbohydrates and other organic materials. Nutrient compounds provided by mycorrhizal fungi include sugar, vitamins, amino acids and other compounds that have not been identified. Rhizoctonia sp. produces niacin that can accelerate the germination and growth of orchid seeds. 
It is expected that Rhizoctonia-like mycorrhizae isolated in this study can be inoculated into orchids seedling from in vitro propagation (tissue culture propagation) so that the seedling will be able to grow better compared to those not inoculated with Rhizoctonia-like mycorrhizae, and their growth is similar to orchid species cultivated in nature.

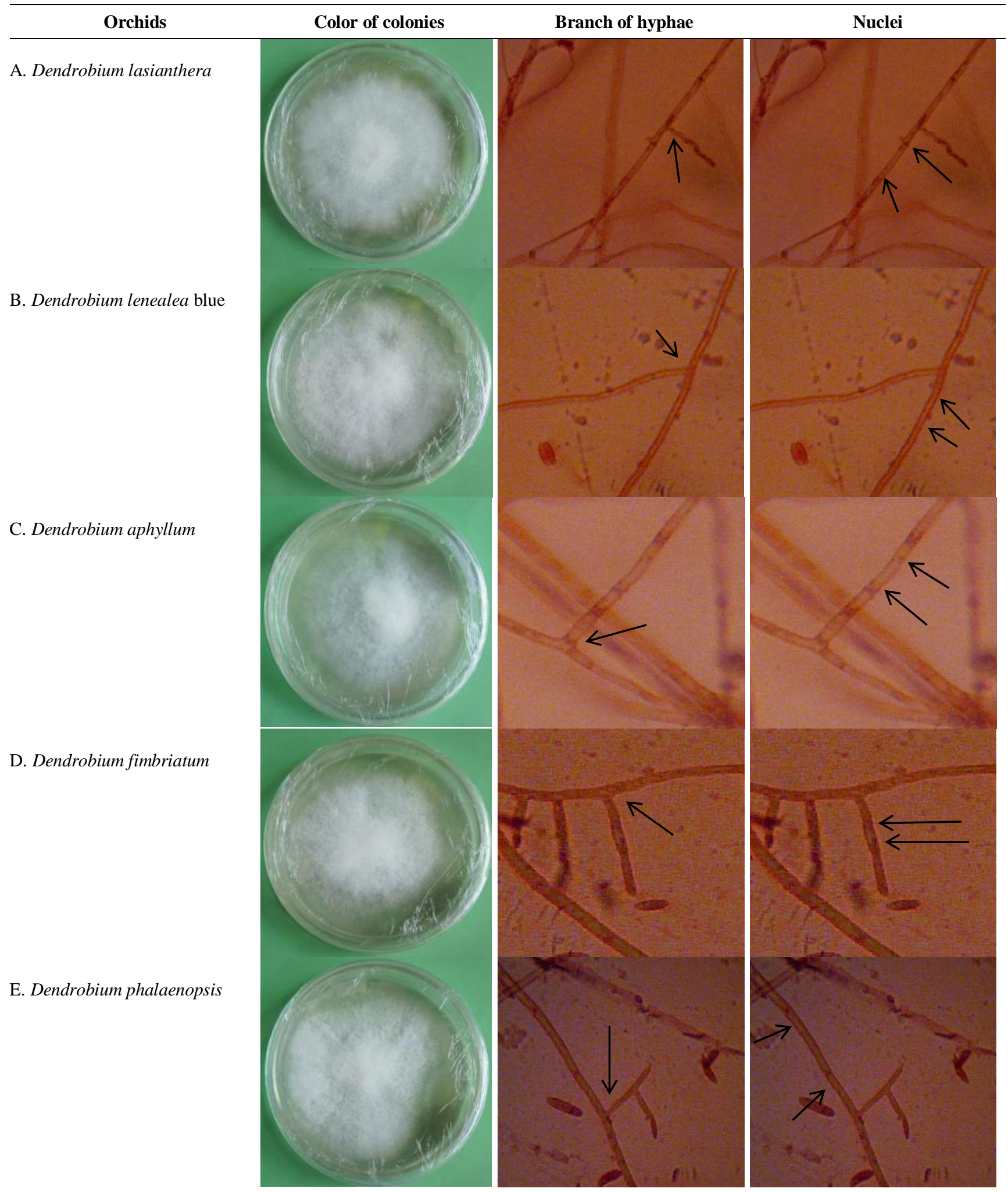

Figure 2. Rhizoctonia-like mycorrhizae colony from five Dendrobium species in Java, Indonesia. Rhizoctonia-like mycorrhizae colonies from: A. Dendrobium lasianthera, B. Dendrobium linealea blue, C. Dendrobium aphyllum, D. Dendrobium fimbriatum, E. Dendrobium phalaenopsis 

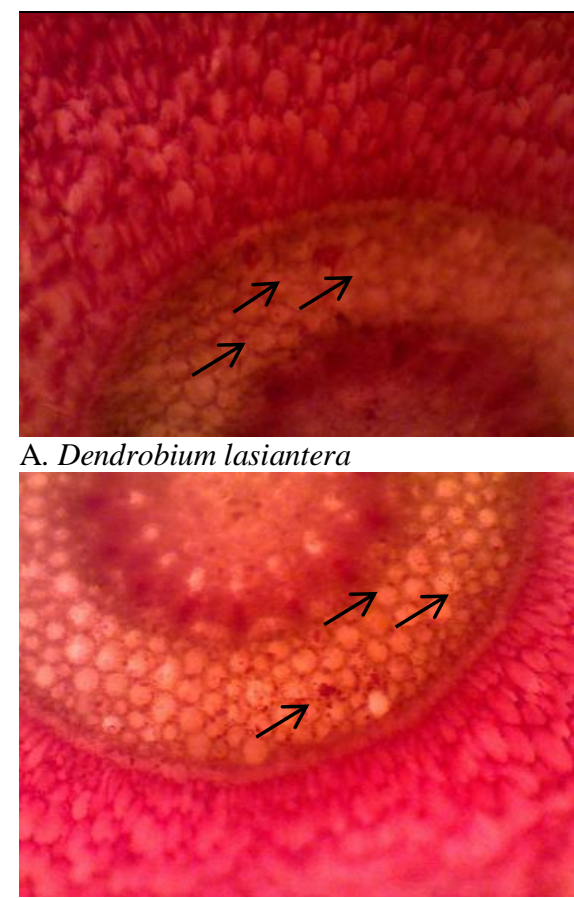

D. Dendrobium fimbriatum

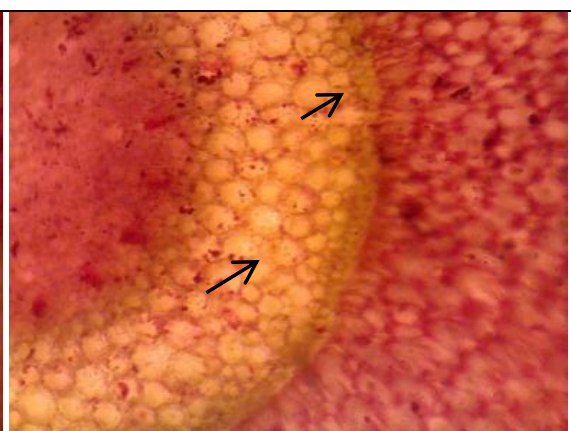

B. Dendrobium leneale blue

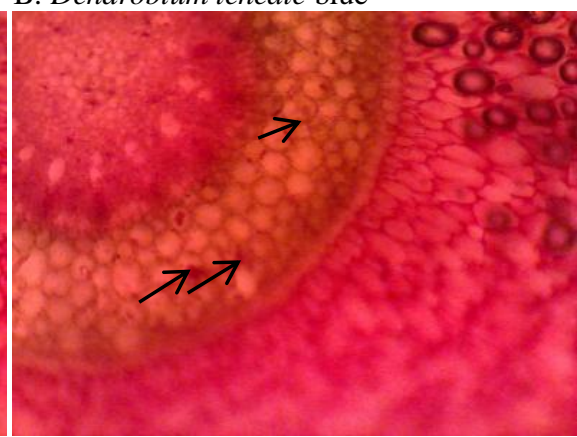

E. Dendrobium phalaenopsis

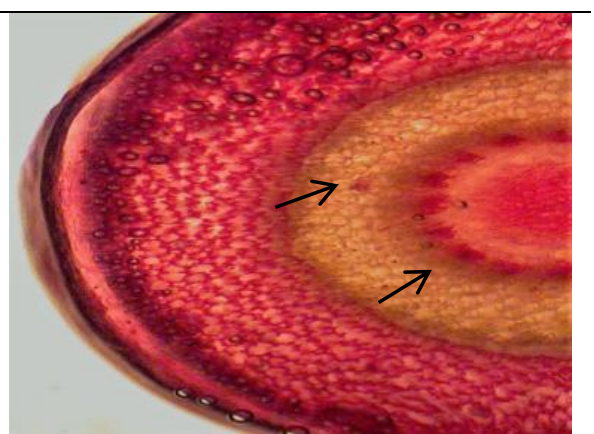

C. Dendrobium aphyllum

Figure 3. Peloton structure of Rhizoctonia-like mycorrhizae from: A. Dendrobium lasianthera, B. Dendrobium linealea blue, C. Dendrobium aphyllum, D. Dendrobium fimbriatum, and E. Dendrobium phalaenopsis

\section{ACKNOWLEDGEMENTS}

We would like to thank the Ministry of Research Technology and the Higher Education, the Republic of Indonesia for financial support through research grants of the fiscal year 2018 Number SP DIPA042.06.1.401516/2018.

\section{REFERENCES}

Athipunyakom P, Manoch L. 2008. Isolation and identification of mycorrhizal fungi from eleven terrestrial orchids. http://www. aseanbiodiversity.info//scripts/count_article. Article_code=53004001. 13 April 2019.

Barnett HL, Hunter BB. 1972. Illustrated Genera of Imperfect Fungi. 3rd ed. Burgess Publishing Company. Minneapolis, MN.

Brundrett MN. 2004. Diversity and classification of mycorrhizal associations. Biol Rev 79: 473-495.

Dressler RL. 1990. The orchids, Natural History and Classification. Harvard University Press. Cambridge, MA.

George EF, Debergh PC. 2008. Micropropagation: Uses and Methods. In: EF George, MA Hall, G-J De Klerk (Eds). Plant Propagation By Tissue Culture. 3rd ed. Vol. 1. Springer, Dordrecht.

Hayakawa S, Uetake Y, Ogoshi A. 1999. Identification of symbiotic Rhizoctonia from naturally occurring protocorms and roots of Dactylorhiza aristata (Orchidaceae). J Fac Agric Hokkaido Univ 6: 129-141.

Lenz LW, Wimber DE. 1959. Hybridization and Inheritance in Orchid. The Ronald Press Company, New York.
Mufidah AL, Ahmad S, Titrim R. 2017. Identifying characteristics of mycorrhizal orchid Dendrobium sp. and Spathoglottis sp. in $\mathrm{pH}$ differences of PDA media. Biosaintropis (Bioscience-Tropic). 3 (2): 51-57.

Northen RT. 1986. Home Orchid Growing. Prentice-Hall Press, New York.

Sadili A. 2011. Diversity, distribution, and utilization of orchid types (Orchidaceae) at Citorek Resort, Gunung Halimun-Salak National Park, West Java. Biosfera 28: 15-22. [Indonesian].

Senthilkumar S, Saravanakumar P, Krishnamurthy KV, John-Britto S. 2001. Morphological and structural features of mycorrhizal roots of Spathoglottis plicata and Dendrobium species. Phyta 5: 1-7.

Siddiqui AZ, Pichtel J. 2008. Mycorrhizae: an Overview, Mycorrhizae: Sustainable Agriculture and Forestry. Springer Science + Business Media B.V., Berlin.

Smith SE, Read DJ. 2008. Mycorrhiza Symbiosis. 3rd ed. Academic Press. New York.

Sneh B, Burpee L, Ogoshi A. 1991. Identification of Rhizoctonia-like Species. APS Press. St. Paul. MN.

Soelistijono R, Priyatmojo A, Sumardiyono C, Semiarti E. 2011. Characterization pathogenic Rhizoctonia sp. and michorrhizal Rhizoctonia isolates on soil orchid Spathoglottis plicata. Biota 16 (2): 371-380.

Soelistijono. 2015. Study on effectiveness mycorrhizal Rhizoctonia sp in plain high and low plain on Disease Severity Index (DSI) Phalaenopsis amabilis to Fusarium sp. Biosaintifika 7 (2): 112-119.

Widiastuti D, Solvia N, Soedarjo M. 2010. The potential of Dendrobium orchids in increasing the variety and quality of cut flower orchids. Agric Res Dev J 29: 101-106.

Withner CL. 1959. The Orchid. The Ronald Press Company, New York.

Zumri M, Daryanti, Soelistijono R. 2017. Isolation and identification of mycorrhizal Rhizoctonia-like of Vanda tricolor orchid from Kopeng, Central Java. Agrineca 17 (1): 51-57. 